\title{
Breath tests for functional gastrointestinal disorders: When and for what?
}

\author{
Nipaporn Pichetshote* and Ali Rezaie
}

Division of Digestive and Liver Diseases, Cedars-Sinai, Los Angeles, CA

\section{RESUMEN}

Las pruebas respiratorias se han utilizado durante mucho tiempo como una valiosa herramienta de diagnóstico en medicina. Ello se debe probablemente a las siguientes ventajas: no son invasivas, son fáciles de realizar y es posible llevar a cabo pruebas repetitivas. Las pruebas respiratorias tienen una amplia variedad de indicaciones y se han utilizado para explorar la fisiopatología de los trastornos gastrointestinales funcionales (FGID). Las pruebas respiratorias con hidrógeno y metano a menudo se utilizan para evaluar los FGID, pero hay que tener en cuenta varias advertencias en su metodología e interpretación. El reciente lanzamiento de las directrices de consenso de América del Norte proporciona uniformidad a estas pruebas respiratorias en un intento de estandarización. Esta revisión explora el papel del metano/hidrógeno y también las pruebas respiratorias de vaciado gástrico de carbono 13 en los FGID, específicamente el síndrome de intestino irritable (IBS), los síntomas similares al IBS y la dispepsia funcional. Revisamos el papel de las pruebas respiratorias en los FGID y cómo no solo proporcionan información de diagnóstico, sino también sobre los mecanismos fisiopatológicos que subyacen a estos trastornos. Esto, en última instancia, puede proporcionar la información necesaria para un tratamiento guiado en estos trastornos, a veces difíciles de tratar. (NeuroGastroLatam Rev. 2018;2:87-97) Corresponding author: Nipaporn Pichetshote, Nipaporn.Pichetshote@cshs.org

Palabras clave: Prueba respiratoria con hidrógeno y metano. Trastorno gastrointestinal funcional. Sobrecrecimiento bacteriano del intestino delgado. Bacterias reductoras de sulfato. Síndrome de intestino irritable. Prueba de aliento con carbono 13. 


\section{ABSTRACT}

Breath tests (BTs) have long been used as a valuable diagnostic tool in medicine. Their longevity in the diagnostic realm is likely due to the following advantages: they are noninvasive, easy to perform, and capable of repetitive testing. BTs have a variety of indications and have been used to explore the pathophysiology of functional gastrointestinal disorders (FGIDs). Hydrogen and methane BTs are often used to evaluate FGIDs but have several caveats to its methodology and interpretation. The recent release of the North American consensus guidelines provides uniformity to these BTs in attempts to provide standardization. This review explores the role of methane/hydrogen and also gastric emptying carbon-13 BTs in FGIDs, specifically irritable bowel syndrome (IBS), IBS-like symptoms, and functional dyspepsia. We review the role of BTs in FGIDs and how they not only provide diagnostic information, but the pathophysiologic mechanisms that drive these disorders. This, ultimately, can provide guided treatment for these disorders that at times can be difficult to manage.

Key words: Hydrogen methane breath test. Functional gastrointestinal disorder. Small intestinal bacterial overgrowth. Sulfate-reducing bacteria. Irritable bowel syndrome. 13C breath test.

\section{INTRODUCTION}

In the field of gastroenterology, breath tests (BTs) are used as diagnostic tools that allow indirect, non-invasive, and relatively less cumbersome evaluation of several disorders by quantifying the appearance in exhaled breath of a metabolite of a specific substrate administered.

The history of breath analysis goes back to the time of Hippocrates. He asked his students to detect diseases by the smell of the breath of patients, like the smell of rotten apples indicated diabetic ketoacidosis, and the smell of urine indicated renal failure. Further with more achievements in science and technology, in the $18^{\text {th }}$ century Lavoisier (father of chemistry) discovered $\mathrm{CO}_{2}$ gas in exhaled breath, and the alcohol BT was first initiated in the early 1950s ${ }^{1}$.

The scientification of medicine and gastroenterology began during the latter part of the $19^{\text {th }}$ century when the discovery of bacterial causes of disease revealed the potential of research in the discovery of new knowledge. It was Linus Pauling's milestone discovery of 250 unique substances present in exhaled breath that offered promising insight into breath testing ${ }^{2}$.

In the 1970s, the concept of lactose malabsorption was then evaluated using hydrogen breath testing. Newcomer and his associates in 1975 studied lactose malabsorption by analyzing breath $\mathrm{H}_{2}$ and $\mathrm{CO}_{2}$ labeled lactose and blood sugar ${ }^{3}$. They showed the supremacy of 
$\mathrm{H}_{2}$ breath measurement for the detection of lactose malabsorption. In 1978, Bond and Levitt further used breath $\mathrm{H}_{2}$ to conclude that some disaccharides remain unbroken and unabsorbed in small intestine due to incomplete digestion. They concluded from the result of a change in $\mathrm{H}_{2}$ concentration in expired air after ingested sugar reached colon undigested and intact ${ }^{4}$. At that time, $\mathrm{H}_{2}$ breath testing replaced blood tests where lack of blood glucose response to lactose malabsorption lead to conclusion that lactose was not digested.

Today, various hydrogen, methane, and carbon BTs are available for diagnosing multiple gastrointestinal (GI) disorders. The aim of this review is to provide insight into the principles, methods of analysis, and performance parameters of various BTs that are available for evaluation of functional GI disorders, with a focus on hydrogen and methane-based breath testing and carbon BTs.

\section{INDICATIONS FOR HYDROGEN AND METHANE BREATH TESTING}

BTs are important for in the evaluation of patients with abdominal pain, bloating, flatulence, and altered bowel movements (diarrhea and/or constipation). Irritable bowel syndrome (IBS), a common functional GI disorder with high global prevalence (11.2\%) and carbohydrate malabsorption, can present with such symptoms ${ }^{5-7}$.

\section{IBS AND IBS-LIKE SYMPTOMS}

Over the last decade, it has been hypothesized and proven through qualitative and quantitative tests that gut flora play a role in the pathophysiology of IBS ${ }^{8-10}$. The increase in the study of gut bacteria has led to grow evidence for a pathophysiological mechanism in the development of IBS based on the presence of alterations in small intestinal bacterial populations ${ }^{11-13}$. One hypothesis is that excessive bacteria reside in the small bowel secondary to motility abnormalities in patients with IBS. This is termed as small intestinal bacterial overgrowth $(\mathrm{SIBO})^{14}$.

SIBO is defined as overgrowth of bacteria $\geq 10^{5}$ colony-forming unit (CFU) per $\mathrm{mL}$ of jejunal aspirate ${ }^{15}$. Some suggest that a colony count of $\geq 10^{3} \mathrm{CFU} / \mathrm{mL}$ of jejunal aspirate should also be considered as SIBO, especially in irritable bowel syndrome (IBS) ${ }^{16}$.

The SIBO hypothesis proposes that it is this expansion of bacteria into the small intestine that leads to symptoms including bloating, abdominal discomfort, and changes in stool form ${ }^{17}$. Using lactulose breath testing and small bowel aspiration, a significant of subjects diagnosed with IBS has $\mathrm{SIBO}^{18}$.

While small bowel aspiration is considered the gold standard test to diagnose SIBO, quantification of hydrogen and methane gas in breath samples remains the most inexpensive, non-invasive, and widely available test for the diagnosis of $\mathrm{SIBO}^{16}$. Human cells are not capable of producing methane-or hydrogen gas $^{19}$. The presence of these gases in the human breath exclusively signifies the metabolism of carbohydrate residues by gut bacteria, their absorption from the gut into the systemic circulation, and expiration through lungs (Fig. 1). Based on this principle, when lactulose or glucose is given to a patient with 


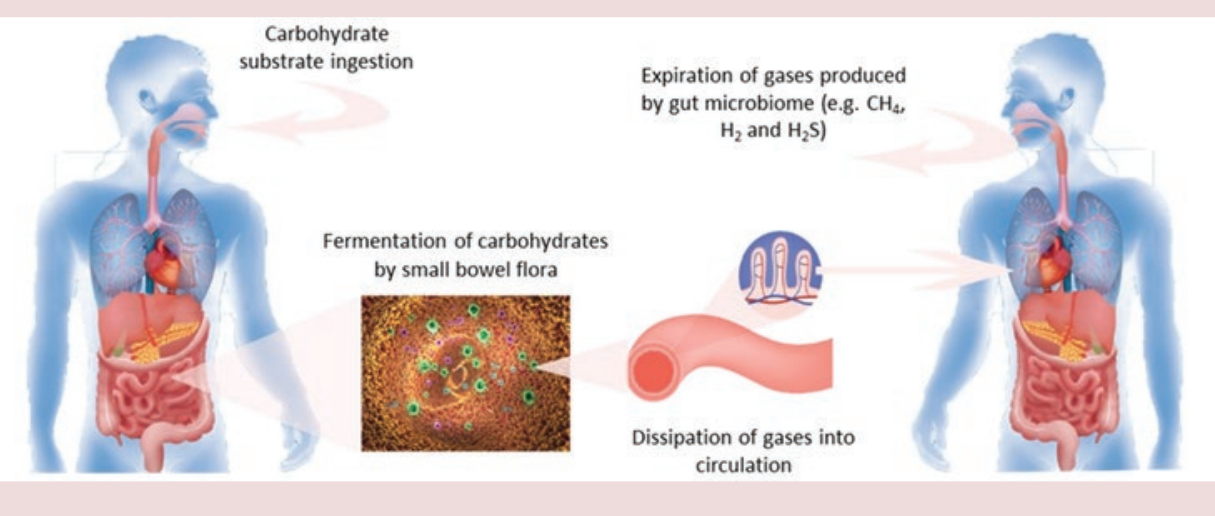

FigurE 1. Schematic drawing showing the principles behind breath testing for small intestinal bacterial overgrowth.

presumed SIBO, the changes in hydrogen and methane concentrations in sequential breath samples will indicate the presence of $\mathrm{SIBO}^{20}$.

The accuracy of BTs in diagnosing SIBO has undergone significant debate. This debate is largely driven by the possibility that the rise in hydrogen and methane could be coming from colonic bacterial fermentation instead of fermentation occurring from excessive bacteria in the small intestine. Two particular studies looked at this. Yu et al. performed a study that looked at radiolabeled lactulose BT in IBS patients and found that at the time of increase in hydrogen, there was an accumulation of the radionucleotide in the cecum ${ }^{21}$. Lin and Massey looked at glucose BTs and concurrent scintigraphy and found that at $90 \mathrm{~min}$ the head of the bolus reached the cecum ${ }^{22}$. This argument has been refuted by the fact that these studies rely on the arrival of the medium to the cecum to determine orocecal transit $(5 \% \text { arrival technetium in cecum })^{23}$ or "head of the labeled bolus." ${ }^{24}$ However, what this suggests that the majority of the medium is still in the small intestine and is being actively fermented by the small bowel flora; hence, the rise of breath gases is not necessarily due to cecal bacterial fermentation. Moreover, fermentation of sugar by cecal bacteria does take some time, and therefore, the arrival of the medium in the intestine does not equate fermentation ${ }^{25}$.

In a systematic review, Khoshini et al. found 11 studies that have attempted to validate the accuracy of breath testing in diagnosis of $\mathrm{SIBO}^{16}$. The sensitivity of glucose breath testing varied from $20 \%$ to $93 \%$ and specificity from $30 \%$ to $86 \%$. The sensitivity of lactulose breath testing ranged from $31 \%$ to $68 \%$ and specificity ranged from $44 \%$ to $100 \%$. In a recent comparative study, duodenal culture was positive in $62 / 139(45 \%)$ patients with unexplained gas, bloating and diarrhea, and negative endoscopy, whereas glucose BT was positive in $38 / 139$ (27\%) patients. The sensitivity and specificity of glucose BT were $42 \%$ and $84 \%$, respectively ${ }^{24}$. In a recent meta-analysis of 19 studies including 888 healthy subjects, we showed that the specificity of the lactulose BT $(90 \%, 95 \%$ CI $88-93 \%)$ is only modestly lower than glucose BT $(98 \%, 95 \%$ CI $97-99 \%)^{25}$. The large ranges of test characteristics of breath testing are due to striking differences in methodology in the included 
studies as none of these studies used an identical approach ${ }^{18}$. This variability in methodology encompassed the preparation, substrate dosing, performance, and interpretation of breath testing. Therefore, to optimize patient care and research, a standardized evidence-based framework on breath testing was brought forward in 2017 by the North American consensus group ${ }^{26}$.

Multiple patterns of hydrogen and methane production have also been described in the literature such as hydrogen predominant, methane predominant, mixed hydrogen/ methane bacterial overgrowth, and flatline (non-methane and fixed hydrogen production) (Fig. 2) ${ }^{27}$. Studies have shown that the type of bacterial colonization of the gut appears to be important in the expression of IBS symptom phenotype ${ }^{14}$.

\section{Hydrogen-predominant SIBO}

The link between enteric flora and a role in IBS symptoms has been long established in patients with IBS accompanied by a diarrheal component. In a study evaluating SIBO in 204 Rome II IBS patients, it was seen that in the group of patients with IBS-D, there were more hydrogen $\left(\mathrm{H}_{2}\right)$ producers during glucose breath testing ${ }^{13}$. An earlier study it was also demonstrated that the type of gas produced by IBS subjects on lactulose BT was predictive of their subtype of IBS. 84 subjects who met Rome I criteria for IBS with abnormal BTs where divided into three groups: constipation severity equal to diarrhea, diarrhea predominant, and constipation predominant. It was found in the diarrhea-predominant subjects with abnormal BTs, no methane excretion was detected ${ }^{18}$. There are some data that suggest even a basal breath hydrogen in a fasting state may be higher in patients with IBS-D ${ }^{28}$.

At present, an early rise in hydrogen levels $\geq 20$ ppm above baseline within $90 \mathrm{~min}$ of the test is considered positive as recommended by the North American consensus statement ${ }^{26}$. A late rise in hydrogen levels occurring after 90 min may be due to normal fermentation of sugar substrate by the colonic flora rather than bacteria in the small bowel.

\section{Methane-predominant SIBO}

Methane $\left(\mathrm{CH}_{4}\right)$ gas has been shown to inhibit intestinal transit in dogs by $59 \%$. In human subjects, $\mathrm{CH}_{4}$ positivity on $\mathrm{BT}$ has been associated with constipation. Patients with $\mathrm{CH}_{4}$-predominant bacterial overgrowth usually present with bloating and abdominal distention. However, they are 5 times more likely to have constipation as opposed to $\mathrm{H}_{2}$-predominant overgrowth. The excessive excretion of methane alone can be seen in IBS- $\mathrm{C}^{30}$ while the severity of constipation directly correlated with the methane level. ${ }^{31}$ The choice of antibiotics for the treatment of SIBO differs between these two groups as the predominant methanogen in the human gut, Methanobrevibacter smithii, is resistant to many antibiotics ${ }^{32}$. At present, a methane level $\geq 10 \mathrm{ppm}$ is considered positive as recommended by the North American consensus statements ${ }^{26}$.

\section{Flatline}

When there is a flatline (non-methane and fixed hydrogen production) on breath testing, 


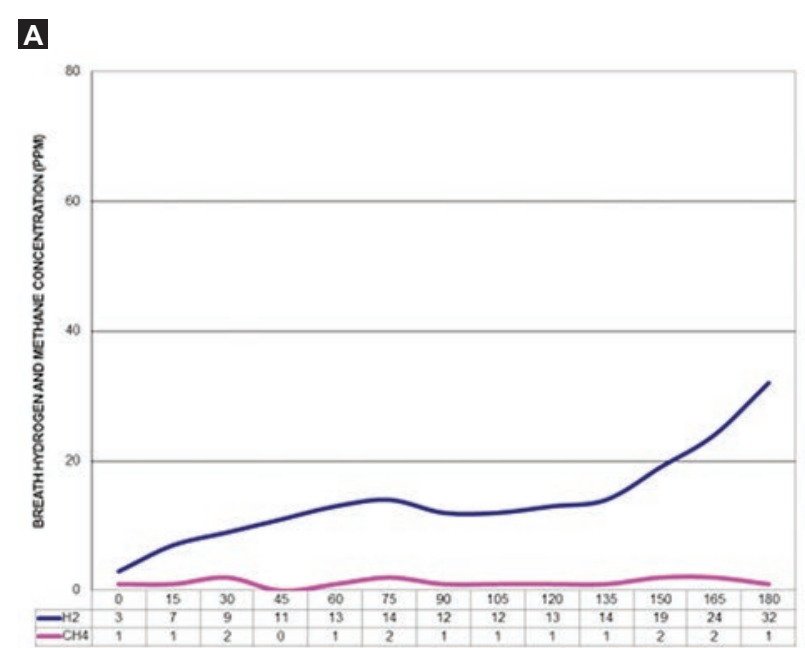

C
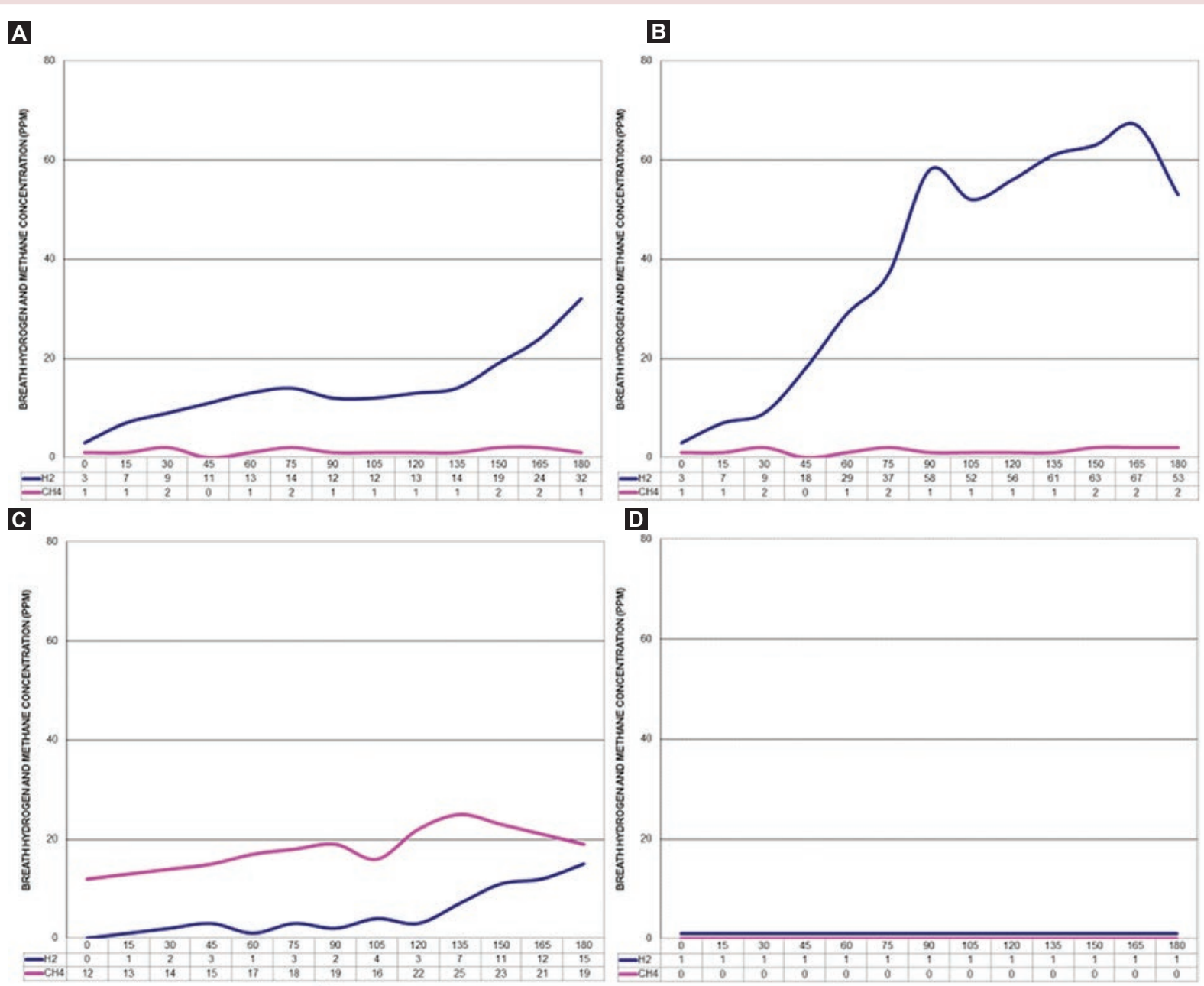

D

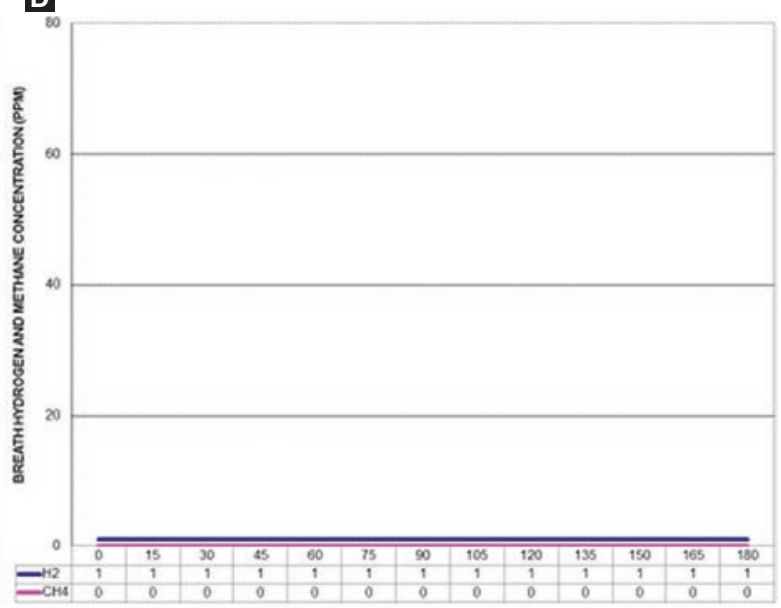

$\mathbf{E}$

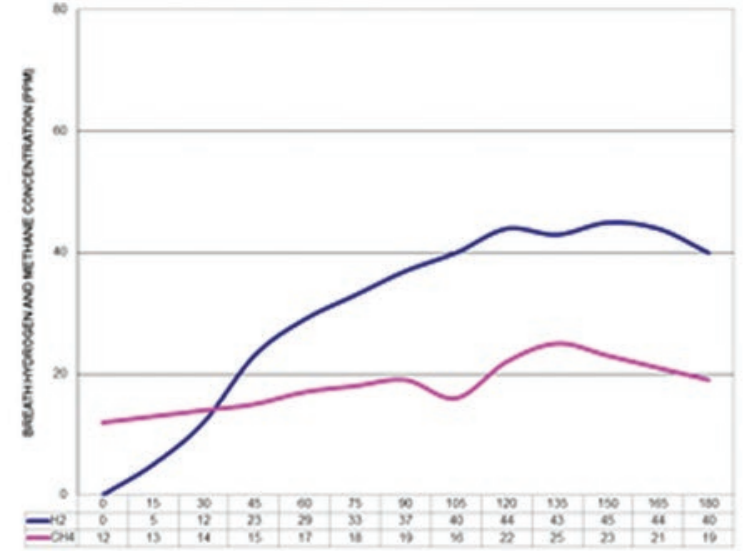

Figure 2. Common patterns of hydrogen and methane breath testing. A shows a graph of a normal breath test with no evidence of excessive methane or early rise of hydrogen. The late rise in hydrogen is due to colonic fermentation. B shows an early rise of hydrogen within the first 90 min of the test which is positive for hydrogen-predominant small intestinal bacterial overgrowth (SIBO). C shows a graph that is positive for methane-predominant bacterial overgrowth. D shows a graph that is "flatline." Image E shows a graph that is positive for hydrogen- and methane-predominant SIBO. 
there is a concern for hydrogenotrophic bacteria. Consumption of hydrogen leads to low levels in exhaled breath. Meanwhile, methanogenic archaea are incapable of producing methane in the absence of hydrogen which is the main substrate for methanogenesis ${ }^{33}$.

Sulfate-reducing bacteria are hydrogenotrophic and their overgrowth can lead to a flatline pattern. Overgrowth of sulfate-reducing bacteria is thought to play an important role in patients with IBS ${ }^{34}$. An association was found between bacterial-derived hydrogen sulfide $\left(\mathrm{H}_{2} \mathrm{~S}\right)$ and visceral hypersensitivity. $\mathrm{H}_{2} \mathrm{~S}$ is known to act as gaseous neurotransmitters inducing the contraction of detrusor muscle in the urinary bladder ${ }^{35}$. A study done by Banik et al. has shown that $\mathrm{H}_{2} \mathrm{~S}$ produced by sulfate-reducing bacteria may play a role in pathogenesis of SIBO. The author suggested that breath $\mathrm{H}_{2} \mathrm{~S}$ could be considered as potential noninvasive biomarker for diagnosis of SIBO among patients with IBS- $\mathrm{D}^{36}$.

In a recent abstract by our group, we showed that in subjects that produce a flatline, they were positive for $\mathrm{H}_{2} \mathrm{~S}$, using a new four gases $\left(\mathrm{H}_{2}, \mathrm{CH}_{4}, \mathrm{H}_{2} \mathrm{~S}\right.$, and $\left.\mathrm{CO}_{2}\right)$ detection device. $\mathrm{H}_{2} \mathrm{~S}$-positive subjects exhibited a diarrhea-predominant pattern ${ }^{37}$.

\section{Carbohydrate malabsorption}

Undigested or poorly digested carbohydrates generate an osmotic force driving water into the lumen of the small bowel and leading to decrease transit times of bowel contents which then reach the colonic flora producing fermentation of this carbohydrate ${ }^{38}$. This may result in symptoms including abdominal pain, excessive gas, bloating, and variable diarrhea, especially in patients with visceral hypersensitivity ${ }^{39}$.

IBS-like symptoms can also be seen in carbohydrate malabsorption ${ }^{40}$. However, symptom profiles of these patients are non-specific and clinical history alone cannot differentiate carbohydrate malabsorption and IBS.

The principle behind carbohydrate malabsorption BT is similar to that behind BTs used to diagnose SIBO. Gut bacteria generally produce hydrogen gas during fermentation of carbohydrates. In bowel, bacteria can only do this when dietary carbohydrates are not absorbed in small intestine and stay as undigested material as it travels along the digestive tract into large intestine Although some of the hydrogen gas produced by the bacteria is expelled as flatus or in making other molecules such as sulfides, acetate, and short-chain fatty acids, most of the gas is absorbed across the lining of the large intestine into bloodstream. The gas is then transported to lungs through the bloodstream and from blood it is exchanged into the airways of lungs and breathed out ${ }^{41}$. At present, any rise (early or late) in hydrogen levels $\geq$ 20 ppm above baseline during a 3-hour test is considered positive for the diagnosis of lactose or fructose malabsorption as recommended by the North American consensus statement.

A study done by Wilder-Smith looked at fructose and lactose malabsorption based on positive breath testing in patients with the diagnosis of functional GI disorders based on Rome III criteria. Malabsorption occurred in $45 \%$ with fructose, $32 \%$ with lactose, and $16 \%$ 
with both ${ }^{42}$. Other studies reported a prevalence of fructose malabsorption in patients with the diagnosis of functional dyspepsia (FD) or unexplained GI symptoms between $40 \%$ and $73 \%{ }^{43}$. In patients with suspected IBS, it is estimated that up to one-third of patients may have dietary fructose intolerance $^{44}$.

It should be noted that in the presence of SIBO, fructose and lactose are prematurely exposed to excessive small intestinal bacterial composition that will lead to early fermentation and elevation of exhaled gases ${ }^{45,46}$. Therefore, performance of a lactulose or glucose BT to rule out SIBO should be considered before carbohydrate malabsorption breath testing to minimize false-positive results $^{26}$. Nucera et al. further confirmed this by showing that the number of positive fructose BTs in IBS patients with positive lactulose tests dropped from $62 \%$ to $3 \%$ after 1 week of antibiotic treatment ${ }^{47}$.

Sucrase insufficiency has also been identified as a cause of carbohydrate malabsorption that can cause IBS and IBS-like symptoms. Malabsorption of this disaccharide, sucrose, has been also been found to be causally involved in functional GI disorders (FGIDs) ${ }^{48}$.

\section{BTs and gastric emptying (GE)}

GE can be measured directly or indirectly. Direct methods include echography, scintigraphy, and $\mathrm{MRI}^{49}$. Scintigraphy remains the most cost-effective, simple, and widely available technique to confirm the presence of delayed GE. However, there exit alternative approaches for the assessment of GE such as
${ }^{14} \mathrm{C}$ or the safer, non-radioactive ${ }^{13} \mathrm{C}$ breath testing using octanoate, spirulina, or acetate incorporated into a solid or liquid meal ${ }^{50}$. ${ }^{13}$ Carbon BTs have the advantage of avoiding radiation associated with scintigraphy.

The carbon BT technique is based on the principle that post-gastric substrate processing is uniform, and therefore, $\mathrm{GE}$ is the rate-limiting step of ${ }^{13 / 14} \mathrm{CO}_{2}$ breath excretion. Once the meal reached the duodenal lumen, the ${ }^{13 / 14} \mathrm{C}$ is rapidly absorbed through the intestinal mucosa and oxidized to $\mathrm{CO}_{2}$ in the liver. The appearance of ${ }^{13 / 14} \mathrm{CO}_{2}$ in the breath after oral administration of $13 / 14 \mathrm{C}$ depends mainly on the GE of the substrate into the duodenum (this is the rate-determining step). The other metabolic steps (absorption and oxidation) do not influence the rate of breath ${ }^{13 / 14} \mathrm{CO}_{2}$ excretion (Fig. 3). ${ }^{51,52}$

Different substrates used can be attached to different meal forms. ${ }^{13 / 14} \mathrm{C}$-octanoate and ${ }^{13} \mathrm{C}$-spirulina are used to label the solid components of test meals and the acetate is utilized to label fluids. Given its safety profile and ease of use, it has been used to evaluate GE in patients with functional gastroduodenal disorders, mainly FD.

\section{BTS AND FD}

According to Rome IV criteria, FD is defined as the predominant presence of one or more symptoms including bothersome postprandial fullness or early satiation (postprandial distress syndrome or [PDS]), epigastric pain (epigastric pain syndrome or [EPS]), or epigastric burning, occurring for the past 3 months with the onset occurring at least 


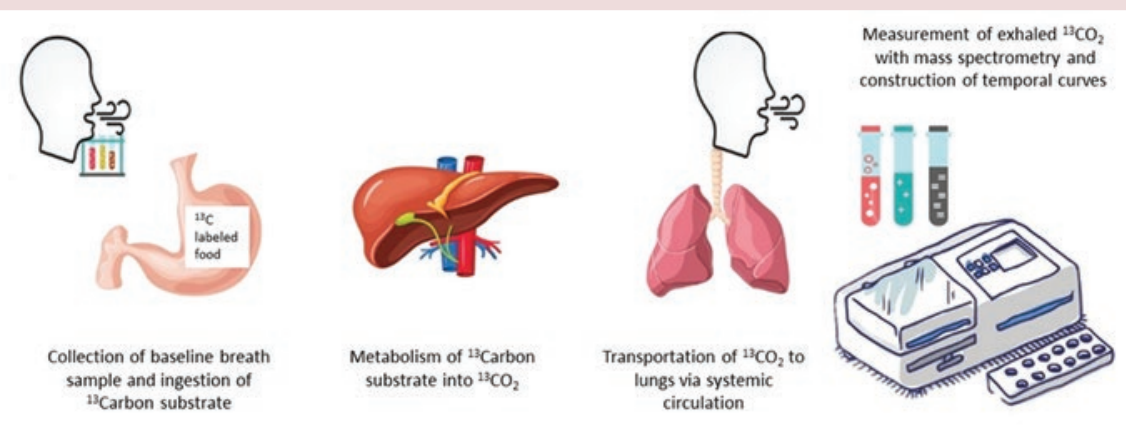

Figure 3. General methodology of breath test analysis using ${ }^{13} \mathrm{C}$-labeled substrates for the study of gastric emptying ${ }^{52}$.

6 months before diagnosis, in the absence of evident structural disease ${ }^{53,54}$. Globally, the prevalence of FD has been noted to vary between $11 \%$ and $29.2 \%{ }^{55}$.

The pathogenesis of FD is likely multifactorial and still unclear; however, impaired GI motility with delayed GE, impaired gastric accommodation after ingestion of a meal, and gastric and duodenal hypersensitivity to distension and intraluminal contents seem to play a role in a subset of patients ${ }^{56}$.

A study done by Haag et al. looked at the GE time measured by ${ }^{13} \mathrm{C}$-octanoic BTs and asymptomatic blood donors, symptomatic blood donors (with recurrent abdominal pain/discomfort), and subjects diagnosed FD or IBS. Symptoms were assessed using a bowel disease questionnaire and the most bothersome symptom complex identified (dysmotility-type dyspepsia, ulcer-type dyspepsia, or IBS). GE time $\left(t_{1 / 2}\right)$ was significantly longer in blood donors with FD symptoms (99 $\mathrm{min}$ ) and FD patients (110 min) compared with asymptomatic controls $(76.7 \mathrm{~min}$ ) but was not significant in subjects with IBS symptoms subjects diagnosed with IBS ${ }^{57}$.
A more recent study done by Vanheel et al. investigated the presence of gastric sensorimotor dysfunction and its possible association with symptom scores in the PDS, EPS, and overlap groups as defined by the Rome III criteria. 284 FD patients underwent a ${ }^{14} \mathrm{C}$-octanoate BT to assess GE. The prevalence of gastric hypersensitivity, impaired gastric accommodation, and delayed GE in the total entire study was $\sim 37 \%, 37 \%$, and $23 \%$, respectively, in concordance with previous reports ${ }^{58-60}$. The study did not find any differences between the Rome III subgroups in the prevalence of delayed GE; along with no differences between gastric hypersensitivity and impaired gastric accommodation. The gastric half-emptying time, however, was significantly higher in the overlap group compared with the EPS group $^{61}$.

Unfortunately, the relationship between GE and FD remains controversial. Unlike the two above studies, Shindo et al. have reported slower GE in PDS patients compared with EPS patients ${ }^{62}$. Other studies also did not detect an association of delayed GE with the subgroups $^{63,64}$. 


\section{CONCLUSION}

\section{Breath testing can be helpful in determining} the pathophysiologic mechanism behind FGIDs. At present, in clinical practice, BTs are being performed with various substrates for a range of established and unestablished indications (e.g., SIBO, carbohydrate malabsorption, and GE time).

\section{Hydrogen and methane BT have long been} used in the evaluation of functional GI disorders. With the new North American consensus guidelines, there now exists standardization in its investigation and interpretation ${ }^{26}$.

\section{As with the many other modalities evaluating GE and FD, carbon BTs and its significance and utility are this functional GI disorder will need further investigation.}

\section{REFERENCES}

1. Antoine Lavoisier : Founder of Modern Chemistry. Lisa Yount. Available from: http:/ / www.nlb.gov.sg/biblio/13110711. [Last accessed on 2018 May 01].

2. Pauling L, Robinson AB, Teranishi R, Cary P. Quantitative analysis of urine vapor and breath by gas-liquid partition chromatography. Proc Natl Acad Sci U S A. 1971;68:2374-6.

3. Newcomer AD, McGill DB, Thomas PJ, Hofmann AF. Prospective comparison of indirect methods for detecting lactase deficiency. N Engl J Med. 1975;293:1232-6.

4. Bond JH, Levitt MD. Effect of dietary fiber on intestinal gas production and small bowel transit time in man. Am J Clin Nutr. 1978;31:S169-S174.

5. Lovell RM, Ford AC. Global prevalence of and risk factors for irritable bowel syndrome: a meta-analysis. Clin Gastroenterol Hepatol. 2012;10:712-210000.

6. Wang YT, Lim HY, Tai D, et al. The impact of irritable bowel syndrome on health-related quality of life: a Singapore perspective. BMC Gastroenterol. 2012;12:104.

7. Porras R, López-Colombo A, Schmulson M. Increase in Mexican and Latin American scientific articles on irritable bowel syndrome. Rev Gastroenterol Mex. 2015;80:228-35.

8. Yamini D, Pimentel, M. Irritable bowel syndrome and small intestinal bacterial overgrowth. J Clin Gastroenterol. 2010;44:672-5.

9. Ford AC, Spiegel BM, Talley NJ, Moayyedi P. Small intestinal bacterial overgrowth in irritable bowel syndrome: systematic review and meta-analysis. Clin Gastroenterol Hepatol. 2009;7:1279-86.

10. Pyleris E, Giamarellos-Bourboulis EJ, Tzivras D, et al. The prevalence of overgrowth by aerobic bacteria in the small intestine by small bowel culture: relationship with irritable bowel syndrome. Dig Dis Sci. 2012;57:1321-9.
11. Posserud I, Stotzer PO, Björnsson ES, Abrahamsson H, Simrén M. Small intestinal bacterial overgrowth in patients with irritable bowel syndrome. Gut. 2007;56:802-8.

12. Pimentel M, Chow EJ, Lin HC. Eradication of small intestinal bacterial overgrowth reduces symptoms of irritable bowel syndrome. Am J Gastroenterol. 2000;95:3503-6

13. Majewski M, McCallum RW. Results of small intestinal bacterial overgrowth testing in irritable bowel syndrome patients: clinical profiles and effects of antibiotic trial. Adv Med Sci. 2007;52:139-42.

14. Sachdev AH, Pimentel M. Antibiotics for irritable bowel syndrome: rationale and current evidence. Curr Gastroenterol Rep. 2012;14:439-45.

15. Ghoshal UC, Ghoshal U. Small intestinal bacterial overgrowth and other intestinal disorders. Gastroenterol Clin North Am. 2017;46:103-20.

16. Khoshini R, Dai SC, Lezcano S, Pimentel M. A systematic review of diagnostic tests for small intestinal bacterial overgrowth. Dig Dis Sci. 2008;53:1443-54.

17. Pimentel M, Lezcano S. Irritable bowel syndrome: bacterial overgrowth-what's known and what to do. Curr Treat Options Gastroenterol. 2007;10:328-37.

18. Pimentel M, Chow EJ, Lin HC. Normalization of lactulose breath testing correlates with symptom improvement in irritable bowel syndrome. A double-blind, randomized, placebo-controlled study. Am J Gastroenterol. 2003;98:412-9.

19. Levitt MD, Bond JH Jr. Volume, composition, and source of intestinal gas. Gastroenterology. 1970;59:921-9.

20. Simrén M, Stotzer PO. Use and abuse of hydrogen breath tests. Gut 2006;55:297-303.

21. Yu D, Cheeseman F, Vanner S. Combined oro-caecal scintigraphy and lactulose hydrogen breath testing demonstrate that breath testing detects oro-caecal transit, not small intestinal bacterial overgrowth in patients with IBS. Gut. 2011;60:334-40.

22. Lin EC, Massey BT. Scintigraphy demonstrates high rate of false-positive results from glucose breath tests for small bowel bacterial overgrowth. Clin Gastroenterol Hepatol. 2016;14:203-8.

23. Triantafyllou K, Pimentel M. Understanding breath tests for small intestinal bacterial overgrowth. Clin Gastroenterol Hepatol. 2016;14:1362-3.

24. Erdogan A, Rao SS, Gulley D, et al. Small intestinal bacterial overgrowth duodenal aspiration vs. glucose breath test. Neurogastroenterol Motil. 2015;27:481-9.

25. Rezaie A, Rao SS. Reply to satta et al. Am J Gastroenterol. 2018;113:440-1.

26. Rezaie A, Buresi M, Lembo A, et al. Hydrogen and methane-based breath testing in gastrointestinal disorders: the North American consensus. Am J Gastroenterol. 2017;112:775-84.

27. Rezaie A, Chua KS, Chang C, Kemmerly T, Pimentel M. Mo2026 methane on breath test predicts altered rectal sensation during high resolution anorectal manometry. Gastroenterology. 2014;146:S-721.

28. Ghoshal UC. How to interpret hydrogen breath tests. J Neurogastroenterol Motil. 2011;17:312-7.

29. Pimentel M, Lin HC, Enayati P, et al. Methane, a gas produced by enteric bacteria, slows intestinal transit and augments small intestinal contractile activity. Am J Physiol Gastrointest Liver Physiol. 2006;290:G1089-95.

30. Kunkel D, Basseri RJ, Makhani MD, et al. Methane on breath testing is associated with constipation: a systematic review and meta-analysis. Dig Dis Sci. 2011;56:1612-8

31. Chatterjee S, Park S, Low K, Kong Y, Pimentel M. The degree of breath methane production in IBS correlates with the severity of constipation. Am J Gastroenterol. 2007;102:837-41.

32. Low K, Hwang L, Hua J, et al. A combination of rifaximin and neomycin is most effective in treating irritable bowel syndrome patients with methane on lactulose breath test. J Clin Gastroenterol. 2010;44:547-50.

33. Gottlieb K, Wacher V, Sliman J, Pimentel M. Review article: inhibition of methanogenic archaea by statins as a targeted management strategy for constipation and related disorders. Aliment Pharmacol Ther. 2016;43:197-212. 
34. Patacchini R, Santicioli P, Giuliani S, Maggi CA. Pharmacological investigation of hydrogen sulfide $\left(\mathrm{H}_{2} \mathrm{~S}\right)$ contractile activity in rat detrusor muscle. Eur J Pharmacol. 2005;509:171-7.

35. Weinstock LB, Klutke CG, Lin HC. Small intestinal bacterial overgrowth in patients with interstitial cystitis and gastrointestinal symptoms. Dig Dis Sci. 2008;53:1246-51.

36. Banik GD, De A, Som S, et al. Hydrogen sulphide in exhaled breath: a potential biomarker for small intestinal bacterial overgrowth in IBS. J Breath Res. 2016;10:026010.

37. Lin E, Kathleen SC, Nipaporn P, et al. Measurement of hydrogen sulfide during breath testing correlates to patient symptoms. Gastroenterology. 2017;152:S205-6.

38. Barrett JS, Gearry RB, Muir JG, et al. Dietary poorly absorbed, short-chain carbohydrates increase delivery of water and fermentable substrates to the proximal colon. Aliment Pharmacol Ther. 2010;31:874-82.

39. Putkonen L, Yao CK, Gibson PR. Fructose malabsorption syndrome. Curr Opin Clin Nutr Metab Care. 2013;16:473-7.

40. Peuhkuri K, Vapaatalo H, Korpela R, Teuri U. Lactose intolerance-a confusing clinical diagnosis. Am J Clin Nutr. 2000;71:600-2.

41. Siddiqui I, Ahmed S, Abid S. Update on diagnostic value of breath test in gastrointestinal and liver diseases. World J Gastrointest Pathophysiol. 2016;7:256-65.

42. Wilder-Smith $\mathrm{CH}$, Materna A, Wermelinger C, Schuler J. Fructose and lactose intolerance and malabsorption testing: the relationship with symptoms in functional gastrointestinal disorders. Aliment Pharmacol Ther. 2013;37:1074-83.

43. Mishkin D, Sablauskas L, Yalovsky M, Mishkin S. Fructose and sorbitol malabsorption in ambulatory patients with functional dyspepsia: comparison with lactose maldigestion/malabsorption. Dig Dis Sci. 1997;42:2591-8.

44. Choi YK, Kraft N, Zimmerman B, Jackson M, Rao SS. Fructose intolerance in IBS and utility of fructose-restricted diet. J Clin Gastroenterol. 2008;42:233-8.

45. Hermans MM, Brummer RJ, Ruijgers AM, Stockbrügger RW. The relationship between lactose tolerance test results and symptoms of lactose intolerance. Am J Gastroenterol. 1997;92:981-4.

46. Sung HY, Kim YS. Fructose malabsorption in patients with irritable bowel syndrome-like symptoms: what is the role in the pathogenesis and clinical implication? J Neurogastroenterol Motil. 2014;20:135-7.

47. Nucera G, Gabrielli M, Lupascu A, et al. Abnormal breath tests to lactose, fructose and sorbitol in irritable bowel syndrome may be explained by small intestinal bacterial overgrowth. Aliment Pharmacol Ther. 2005;21:1391-5.

48. Opekun AR, Balesh AM, Shelby HT. Use of the biphasic (13)C-sucrose/ Glucose breath test to assess sucrose maldigestion in adults with functional bowel disorders. Biomed Res Int. 2016;2016:7952891.
49. Schmidt PT, Abrahamsson H, Dolk A, et al. Methods to assess gastric motility and sensation. Scand J Gastroenterol. 2008;43:1285-95.

50. Schwizer W, Maecke H, Fried M. Measurement of gastric emptying by magnetic resonance imaging in humans. Gastroenterology. 1992;103:369-76.

51. Perri F, Pastore MR, Annese $V{ }^{13} \mathrm{C}$-octanoic acid breath test for measuring gastric emptying of solids. Eur Rev Med Pharmacol Sci. 2005;9:3-8.

52. Bonfrate L, Grattagliano I, Palasciano G, Portincasa P. Dynamic carbon 13 breath tests for the study of liver function and gastric emptying. Gastroenterol Rep (Oxf). 2015;3:12-21.

53. Stanghellini V, Chan FK, Hasler WL, et al. Gastroduodenal disorders. Gastroenterology. 2016;150:1380-92.

54. Schmulson MJ, Drossman DA. What is new in Rome IV. J Neurogastroenterol Motil. 2017;23:151-63.

55. Mahadeva S, Goh KL. Epidemiology of functional dyspepsia: a global perspective. World J Gastroenterol. 2006;12:2661-6.

56. Carbone F, Tack J. Gastroduodenal mechanisms underlying functional gastric disorders. Dig Dis. 2014;32:222-9.

57. Haag S, Talley NJ, Holtmann G. Symptom patterns in functional dyspepsia and irritable bowel syndrome: relationship to disturbances in gastric emptying and response to a nutrient challenge in consulters and non-consulters. Gut. 2004;53:1445-51.

58. Tack J, Bisschops R, Sarnelli G. Pathophysiology and treatment of functional dyspepsia. Gastroenterology. 2004;127:1239-55.

59. Camilleri M, Dubois D, Coulie B, et al. Prevalence and socioeconomic impact of upper gastrointestinal disorders in the United States: results of the US upper gastrointestinal study. Clin Gastroenterol Hepatol. 2005;3:543-52.

60. Vanheel H, Vicario M, Vanuytsel T, et al. Impaired duodenal mucosal integrity and low-grade inflammation in functional dyspepsia Gut. 2014;63:262-71.

61. Vanheel H, Carbone F, Valvekens L, et al. Pathophysiological abnormalities in functional dyspepsia subgroups according to the Rome III criteria. Am J Gastroenterol. 2017;112:132-40.

62. Shindo T, Futagami S, Hiratsuka T, et al. Comparison of gastric emptying and plasma ghrelin levels in patients with functional dyspepsia and non-erosive reflux disease. Digestion. 2009;79:65-72.

63. Haag S, Senf W, Tagay S, et al. Is there any association between disturbed gastrointestinal visceromotor and sensory function and impaired quality of life in functional dyspepsia? Neurogastroenterol Motil.-2010;22:262-e79.

64. Di Stefano M, Miceli E, Tana P, et al. Fasting and postprandial gastric sensorimotor activity in functional dyspepsia: Postprandial distress vs. epigastric pain syndrome. Am J Gastroenterol. 2014;109:1631-9. 